\title{
Study on the Bilingual Teaching Situation of High Vocational Nursing Education
}

\author{
Liu Huan \\ School of nursing \\ Jiangxi University of Technology
}

\begin{abstract}
With the world globalization, it becomes a basic requirement to master English language for modern students, which is a problem for higher vocational education because it focuses mainly on technology and ignores the most basic education while both English and Chinese should be highlighted. This paper analyzes the current situation of bilingual education as well as its influential factors, compares the current situation and development strategies of bilingual teaching class and non- bilingual teaching class so as to conduct a preliminary study on students' final exam record and English exam passing rate to comment on the effect on students caused by bilingual teaching. Therefore, it aims to provide valuable advice and references to carry out bilingual teaching and study on its development strategies.
\end{abstract}

KeyWords-Bilingual Education; Nursing Education;

Teaching Model; Development Strategy

\section{INTRODUCTION}

With economic globalization and increasingly frequent exchange of knowledge and talents, the demand of international talents is soaring. What's more, Internationalized medical market and international nursing services put forward new demands for nursing personnel and people who are familiar with Chinese language and culture as well as foreign language and culture have become important indicators for China to compete in international market. Therefore, the cultivation of international nursing personnel brings along with new challenges and opportunities for China's nursing education. At present, nursing education inn China includes vocational school (special school); vocational high school (junior college); undergraduate; master; and doctor, while vocational high school dominant. The main task of vocational high schools is to foster qualified nursing staff and nursing managers. With the development of society, the demand on nursing staffs is higher and the reason for higher vocational education emerging is to cultivate talents who are adapted to science and technology as well as economic development and social progress.

In China, bilingual education refers to adopt another foreign language besides Chinese as the focus to carry out teaching, and in most of conditions, it is English. Bilingual teaching in nursing does not only ask students to learn English but also adopt English especially medical English so as to provide foreign-related health care service, international technical cooperation as well as data transfer, and international nursing services.

\section{GENERAL SITUATION AND DEVELOPMENT OF DOMESTIC BILINGUAL EDUCATION}

Bilingual teaching in Chinese universities is reported in recent ten years while parts of educators begin to explore bilingual teaching based on the inefficiency of English teaching in China, which integrates English teaching in non-language subject teaching, hoping to improve students ' English ability. Therefore, bilingual education becomes a focus of concern in educational theory and educational practice. In addition, a series of exploration activities in terms of bilingual teaching materials, teacher training, teaching and research activities, classroom and discussion have been implemented.

For Chinese Colleges, current bilingual teaching can be divided into three layers and the first layer is simple penetration, namely maintence bilingual education, for example teachers can take advantage of English while teaching professional vocabulary, important vocabulary and structures with Chinese explanation so as to make 
students be exposed to English; the second layer is integration, namely transitional Bilingual education while teachers use English and Chinese in alternation to help students organize language in English and understand its Chinese meaning in the premise of not affecting their understanding of subject knowledge; the third layer is bilingual thinking, namely immersion bilingual education to make students think and solve problems in English so as to cultivate their thinking ability in foreign language. Besides, the immersion comes from French word immerger, which originates from Canada, referring to the special French learning method adopted by English students.

\section{THE CURRENT SITUATION OF BILINGUAL TEACHING} IN NURSING EDUCATION

\section{A. Vague understanding of bilingual education}

At present, domestic education circles have the following opinions toward bilingual teaching: first, bilingual teaching is mainly to impart knowledge; second, bilingual teaching simultaneously teach language and knowledge; third, bilingual teaching is a method of language teaching. Some schools, teachers, and students have vague understanding of bilingual education while some of them hold the idea that speaking English in class can be deemed as bilingual education while some mix bilingual education and professional language learning and some think bilingual teaching is equal to foreign language teaching.

\section{B. Curriculum setting should be reasonable}

There are large differences among various disciplines in terms of characteristics and at present, it is not suitable to carry out bilingual education for all courses. Therefore, it is very important to carry out bilingual education for proper courses. However, the current bilingual course setting is random without forming systems and it shall be difficult to guarantee the education effect.

\section{Imperfect management and supervision system}

Quality standards and monitoring systems of bilingual teaching are important to guarantee the bilingual education effect. Even though some universities and colleges have realized the importance of its teaching quality monitoring system, and begin to set project approval, which yet is fragmented.

\section{BILINGUAL EDUCATION SUGGESTIONS FOR NURSING EDUCATION}

\section{Correctly understand bilingual education}

Bilingual education adopts language as the medium, which emphasizes professional and academic points so as to help students not only grasp course knowledge but also improve comprehensive ability of learning foreign language. Based on this, students are able to have a good knowledge of multi-culture and shall adopt another thinking mode to solve problems and meanwhile carry out academic communication. In bilingual teaching, language learning is closely related to subject learning which shall create mutual promotion effect when language is well understood whereas the opposite.

\section{A. Scientifically set bilingual course and credit hours}

Nursing asks students to learn basic theoretical knowledge in terms of humanities and social sciences, medical foundation, and preventive care and be trained with basic theory, knowledge and clinical nursing skills as well as the basic ability to serve objects in terms of holistic nursing and community health. Therefore, nursing is a comprehensive major, which have to be reformed in order to cultivate high-quality applied talents.

\section{B. Improve the management system for bilingual education}

Bilingual teaching management is a complex and arduous task, covering a wide range, departments and agencies. Therefore, colleges and universities have to strengthen the support on bilingual teaching, improve management level to guarantee its smooth implementation.

\section{CONCLUSION}

Domestic bilingual teaching develops late and obtains experience, which yet has a large improvement and perfection space and is still at the exploratory stage. We can draw the following conclusions based on the above: 
First, to improve the student quality should take their foreign language foundation, learning interests, ability and demand into consideration.

Second, choose proper bilingual teaching materials, analyze merits and demerits so as to adopt the most suitable one based on the real situation of local areas, schools and students.

Perfect the management system of bilingual education system such as make relevant rules as well as regulations, establish learning supervision teams, effective incentives and proper promotion methods.

Strengthen faculty development in terms of bilingual education, for example, carry out on-the-job training, training abroad and employ current talents and introduce talents from outside.

Advance the bilingual education method, for example to combine traditional teaching method and modern teaching method, apply diverse teaching forms etc.

\section{REFERENCES}

[1] White A. Research in Nurse Education Today: do we meet our aims and scope?[J]. Nurse Education Today, 2002, 22(1):págs. 601-608.

[2] Marcinkiw K L. A goal for nursing education.[J]. Nurse Education Today, 2003, 23(3):174-182.

[3] Callister L C, Bond A E, Matsumura G, et al. Threading spirituality throughout nursing education.[J]. Holistic Nursing Practice, 2004, 18(3):160-166.

[4] Calvillo E, Clark L, Ballantyne J E, et al. Cultural Competency in Baccalaureate Nursing Education.[J]. Journal of Transcultural Nursing, 2009, 20(2):137-145.

[5] Reilly, D. E., and M. H. Oermann. "Clinical teaching in nursing education." Nln Publications 36.15-2471(1992):v-xiv, 1-507.

[6] Neil J A. Simulation in Nursing Education[J]. Educational Strategies, 2011, 4(2):97-112.

[7] Achike F I, Nain N. Promoting problem-based learning (PBL) in nursing education: A Malaysian experience.[J]. Nurse Education in Practice, 2005, 5(5):302-11.

[8] Glossop C. Student nurse attrition: use of an exit-interview procedure to determine students' leaving reasons - Nurse Education Today $[\mathrm{J}]$. Nurse Education Today, 2002 22(5):375-386.

[9] Mclaughlin K, Muldoon O T, Moutray M. Gender, gender roles and completion of nursing education: A longitudinal study - Nurse Education Today[J]. Nurse Educ Today, 2010, 30(4):303-307.

[10] Agazio J, Buckley K M. An Untapped Resource: Using YouTube in Nursing Education[J]. Nurse Educator, 2009, 34(1):23-28.

[11] Skiba D J. Nursing Education 2.0: Second Life[J]. Nursing Education Perspectives, 2007, :28(:3):156-7.

[12] Jane Mikkelsen K, Tone Elin M, Berit Rokne H. Nursing education in Norway.[J]. Journal of Advanced Nursing, 2002, 38(3):296-302 